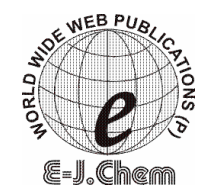

http://www.e-journals.net
ISSN: 0973-4945; CODEN ECJHAO

E-Journal of Chemistry

Vol. 5, No. 1, pp. 74-80, January 2008

\title{
Effluents and Solid Waste Analysis in a Petrochemical Company- A Case Study of Eleme Petrochemical Company Ltd, Port Harcourt, Nigeria
}

\author{
A.U. ISRAEL, I.B. OBOT* ${ }^{*}$ S.A UMOREN, V. MKPENIE and G.A EBONG \\ Department of Chemistry, \\ Faculty of Science, University of Uyo, \\ P.M.B. 1017, Uyo, Nigeria. \\ proffoime@yahoo.com
}

Received 10 May 2007; Accepted 20 July 2007

\begin{abstract}
Effluents and soil samples where sediments from the treated effluents are dumped were analyzed for physicochemical properties, metallic and non-metallic ions. These parameters were compared with established international standard (FEPA). Effluents were classified as process waste water (PWW), clarified water (CW), and final discharge (FD). The petrochemical effluents contained very high concentration of TDS $(284.00 \pm 014 \mathrm{mg} / \mathrm{L})$ and significant concentrations of TSS $(78.89 \pm 0.01 \mathrm{mg} / \mathrm{L})$, COD $(30.10 \pm 0.02 \mathrm{mg} / \mathrm{L})$, DO $(13.20 \pm 0.01 \mathrm{mg} / \mathrm{L})$, BOD $(6.12 \pm 0.00 \mathrm{mg} / \mathrm{L})$, $\mathrm{PO}_{4}{ }^{3-}(4.34 \pm 0.00 \mathrm{mg} / \mathrm{L}), \mathrm{SO}_{4}{ }^{2-}(3.59 \pm 0.00 \mathrm{mg} / \mathrm{L}), \mathrm{Cl}^{-}(55.52 \pm 0.01 \mathrm{mg} / \mathrm{L})$ and $\mathrm{NO}_{3}{ }^{-}(8.40 \pm 0.01 \mathrm{mg} / \mathrm{L})$. Low concentrations of iron, zinc, copper, cadmium, lead, nickel and cobalt was also observed. Some heavy metals were not detected at all in some of the effluent samples analyzed. Apart from temperature and total dissolved solid TDS, all the other parameters were below FEPA effluent limitations for guidelines for Petroleum Refinery, Fuel/Gasoline oil category in Nigeria.
\end{abstract}

Keywords: Petrochemicals, Effluents, Heavy metal, Physicochemical parameters.

\section{Introduction}

Petrochemical plants generate solid waste and sludges, some of which may be considered hazardous because of the presence of toxic organics and heavy metals. Accidental discharges as a result of abnormal operation, especially from polyethylene and ethylene 
oxide-glycol plants in a petrochemical complex, can be a major environmental hazard, releasing large quantities of pollutants and products into the environment ${ }^{1,2}$. The presence of objectionable conditions such as offensive odours and accumulation of debris have been reported to decrease the proper value and recreational uses of water ${ }^{3}$.

Wastewaters released by petrochemical industries are characterized by the presence of large quantities of polycyclic and aromatic hydrocarbons, phenols, metal derivatives, surface-active substances, sulphides, naphthylenic acids and other chemicals ${ }^{4}$. Due to the ineffectiveness of purification systems, wastewaters may become seriously dangerous, leading to the accumulation of toxic products in the receiving water bodies with potentially serious consequences on the ecosystem ${ }^{5}$.

Several investigations have shown positive correlation between pollutions from petrochemical effluents and the health of aquatic organisms. Previous observations suggested a correlation between contamination of water and sediments with aromatic hydrocarbons from petrochemical effluent, and compromised fish health ${ }^{6}$. An earlier study demonstrated the accumulation of heavy metals with accompanying histopathology in Oreochromis niloticus exposed to treated petroleum refinery effluent from the Nigerian National Petroleum Corporation, Kaduna ${ }^{7}$.

The Eleme Petrochemical Plant located in the oil rich Niger Delta in Port Harcourt, Rivers State, Nigeria generates large quantities of effluents daily. These effluents are discharged into natural water bodies after treatment. Though the compositions of the effluents are regulated by various laws, it is not known whether they comply with the legally accepted toxicant levels for refineries and petrochemical plants in Nigeria. Furthermore, the impact of these toxicants on the quality of the effluent receiving water body has not been investigated. The present study investigates the quality of Eleme Petrochemical effluent and is aimed at determining the toxicity level of the effluent produced from Eleme Petrochemical Company Limited Nigeria (EPCL- Nigeria) by determining the concentration levels of the different contaminants.

The treatment procedure of the effluent in the company is as shown below:

Equalization
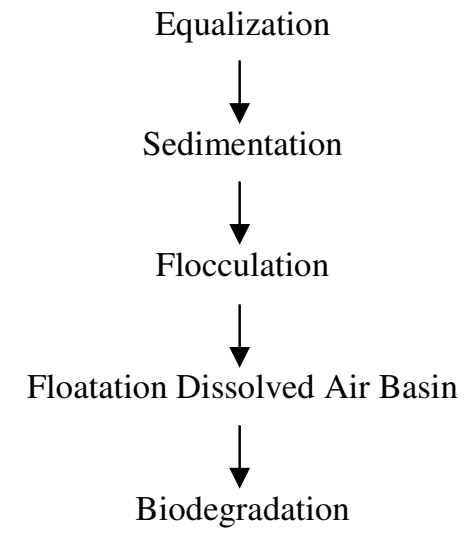

\section{Experimental}

Description of the area of study

Eleme Petrochemical Company Limited (EPCL) is situated in Eleme, Rivers State in the oil rich Niger Delta Area of Nigeria. It was established by the Federal Government of Nigeria in 1988. The major feedstock used in the company is delivered to it in liquid form via pipeline 
from the Liquefied Natural Gas (LNG) plant located at Obiafu/Obrikom in Rivers State. The feedstock is free from methane, but composed of ethane, propane and butane with minor quantities of pentane and heavier hydrocarbons. The major products of the company are low density and linear low-density polyethylene (LLDPE), polypropylene (PP), vinyl chloride monomer, butene and mixture of other olefins.

\section{Sample collection}

Samples were collected once a month between July 2005 and March 2006. Water samples were collected with a 2-litre plastic hydro bios water sampler and transferred to clean 2 litre polyethylene containers and $250 \mathrm{~mL}$ capacity borosilicate glass bottles. The effluents include the process waste water (PWW), clarified water (CW) and the final discharge water (FD) generated by the Eleme Petrochemical Company Limited (EPCL). These were collected in polyethylene containers and borosilicate bottles of the same capacity. They were rinsed several times with water or effluent samples at the point of collection. Sediment samples were collected with benthic sampler and transported in polyethylene bags. All samples were transported in ice chests and analyzed for temperature and $\mathrm{pH}$ within $12 \mathrm{~h}$ of collection. Other physicochemical parameters were analyzed later using refrigerated samples.

\section{Water and sediment analysis}

The temperature was measured using calibrated mercury in glass thermometer $\left(0-100^{\circ} \mathrm{C}\right)$ to the nearest $\pm 0.05^{\circ} \mathrm{C}$. An $\mathrm{HACH} \mathrm{pH}$ meter was used for $\mathrm{pH}$ determination. Determination of Biological Oxygen Demand (BOD), Determination of Dissolved Oxygen (DO), Determination of Chemical Oxygen Demand (COD), The determination of Total Dissolved Solid (TDS), Total suspended solid (TSS), Total Hydrocarbon (THC), $\mathrm{Cl}^{-}, \mathrm{PO}_{4}{ }^{3-}, \mathrm{SO}_{4}{ }^{2-}$, and $\mathrm{NO}_{3}{ }^{-}$were carried out according to standard methods for the examination of water and wastewater previously described ${ }^{8-10}$. A Unicam 919 model atomic absorption spectrophotometer was used for the determination of the heavy metals including nickel (Ni), lead $(\mathrm{Pb})$, zinc $(\mathrm{Zn})$, iron $(\mathrm{Fe})$, copper $(\mathrm{Cu})$, cobalt $(\mathrm{Co})$ and cadmium. Sediment samples were air-dried by thinly spreading on a clean laboratory bench surface at room temperature, and brought to a relatively homogenous state by thoroughly mixing, and sieving with $2 \mathrm{~mm}$ mesh before being treated. In the case of fresh samples, large stones and roots were picked out before mixing and weighing. Moisture determination of duplicate samples of the sediment was carried out for dry weight correction. The sediment samples were then prepared (extraction method) for the various physicochemical determination following procedures of Stewart et al. ${ }^{11}$.

\section{Results and Discussion}

\section{Composition of refinery effluent}

The physicochemical qualities of the major effluents generated in Eleme petrochemical company Limited (EPCL), Port Harcourt were investigated, and the level of contaminants estimated. The concentration of the most significant pollutants in the various petrochemical effluents are shown in Table 1.

Process waste water (PWW) is water that is intended to come into contact with hydrocarbons or treated chemicals at the petrochemical plant. Clarified water $(\mathrm{CW})$ is a combination of PWW and sewage, while the final discharge water (FD) is the effluent, which has undergone both chemical and biological treatment to eliminate or reduce waste contents to acceptable levels. Values represent the mean of seven samples collected over a period of seven months. 
PWW contained the highest concentrations of TDS $(284.00 \pm 0.14 \mathrm{mg} / \mathrm{L})$, THC $(0.79 \pm$ $0.00 \mathrm{mg} / \mathrm{L})$, copper $(0.014 \pm 0.01 \mathrm{mg} / \mathrm{L})$, lead $(0.032 \pm 0.01 \mathrm{mg} / \mathrm{L})$ and sulphate ions $(3.59 \pm$ $0.00 \mathrm{mg} / \mathrm{L})$, and significant quantities of TSS $(76.48 \pm 0.01 \mathrm{mg} / \mathrm{L})$, COD $(28.00 \pm 0.14$ $\mathrm{mg} / \mathrm{L}), \mathrm{DO}(7.14 \pm 0.01 \mathrm{mg} / \mathrm{L}), \mathrm{BOD}(2.04 \pm 0.01 \mathrm{mg} / \mathrm{L}), \mathrm{Cl}^{-}(51.69 \pm 0.01 \mathrm{mg} / \mathrm{L}) . \mathrm{CW}$ on the other hand contained higher concentrations of COD $(30.10 \pm 0.01 \mathrm{mg} / \mathrm{L}), \mathrm{BOD}(4.02 \pm$ $0.00 \mathrm{mg} / \mathrm{L}), \mathrm{DO}(13.20 \pm 0.01 \mathrm{mg} / \mathrm{L}), \mathrm{Cl}^{-}(55.52 \pm 0.01 \mathrm{mg} / \mathrm{L})$ as well as the nutrient compound $\mathrm{PO}_{4}{ }^{3-}(4.34 \pm 0.00 \mathrm{mg} / \mathrm{L})$ than the $\mathrm{PWW}$. Final discharge water FD contained the highest concentrations of TSS $(78.89 \pm 0.01 \mathrm{mg} / \mathrm{L}), \mathrm{NO}_{3}{ }^{-}(8.40 \pm 0.01 \mathrm{mg} / \mathrm{L}), \mathrm{BOD}(6.12 \pm$ $0.01 \mathrm{mg} / \mathrm{L})$, cobalt $(0.300 \pm 0.00 \mathrm{mg} / \mathrm{L})$. Also FD showed a reduction in the level of most of the parameters observed in $\mathrm{CW}$, though significant concentrations of TDS $(60.80 \pm 0.01$ $\mathrm{mg} / \mathrm{L})$, DO $(10.20 \pm 0.00 \mathrm{mg} / \mathrm{L}), \mathrm{COD}(28.60 \pm 0.01), \mathrm{PO}_{4}{ }^{3-}(1.79 \pm 0.01 \mathrm{mg} / \mathrm{L})$ persisted. $\mathrm{CW}$ contained high concentrations of the following parameters including COD (30.10 \pm 0.02 $\mathrm{mg} / \mathrm{L}), \mathrm{DO}(13.20 \pm 0.01 \mathrm{mg} / \mathrm{L})), \mathrm{Cl}^{-}(55.52 \pm 0.01 \mathrm{mg} / \mathrm{L})$ and $\mathrm{PO}_{4}{ }^{3-}(4.34 \pm 0.00 \mathrm{mg} / \mathrm{L})$ which were observed to be higher than in the FD. Temperature and $\mathrm{pH}$ remained fairly constant while zinc and cobalt showed reduction in concentration. Nickel and cadmium were not detected $(<0.01 \mathrm{mg} / \mathrm{L})$ in the petrochemical effluents in all the three samples analyzed. Generally all the heavy metals analyzed were low in concentration as compared to other physicochemical parameters.

Table 1. Physicochemical parameters and some metal/non-metal ions concentration in effluent samples of Eleme Petrochemical Company compared with FEPA standards.

\begin{tabular}{ccccc}
\hline & \multicolumn{2}{c}{ Effluents $(\mathrm{mg} / \mathrm{L})$} & \multicolumn{2}{c}{ FEPA effluent } \\
\cline { 2 - 5 } Parameters & PWW & CW & FD & $\begin{array}{c}\text { limitation guideline } \\
(1991) \mathrm{mg} / \mathrm{L}\end{array}$ \\
\hline Temperature & $29.60 \pm 0.14$ & $30.10 \pm 0.07$ & $29.80 \pm 0.14$ & 30.00 \\
pH & $7.51 \pm 0.01$ & $8.36 \pm 0.02$ & $5.85 \pm 0.01$ & $6-9$ \\
$\mathrm{TDS}$ & $284.00 \pm 0.14$ & $20.00 \pm 0.01$ & $60.80 \pm 0.01$ & 2000 \\
$\mathrm{TSS}$ & $76.48 \pm 0.01$ & $14.90 \pm 0.01$ & $78.89 \pm 0.01$ & 30 \\
$\mathrm{COD}$ & $28.00 \pm 0.14$ & $30.10 \pm 0.02$ & $28.60 \pm 0.01$ & 40 \\
$\mathrm{DO}$ & $7.14 \pm 0.01$ & $13.20 \pm 0.01$ & $10.20 \pm 0.00$ & 20 \\
$\mathrm{BOD}$ & $2.04 \pm 0.01$ & $4.02 \pm 0.00$ & $6.12 \pm 0.00$ & 10 \\
$\mathrm{THC}$ & $0.79 \pm 0.00$ & $\mathrm{ND}$ & $\mathrm{ND}$ & 10 \\
$\mathrm{Fe}$ & $0.013 \pm 0.00$ & $0.095 \pm 0.01$ & $0.083 \pm 0.00$ & 20 \\
$\mathrm{Zn}$ & $0.008 \pm 0.01$ & $0.020 \pm 0.01$ & $0.007 \pm 0.00$ & 1.0 \\
$\mathrm{Cu}$ & $0.014 \pm 0.01$ & $<0.01$ & $0.005 \pm 0.00$ & 1.5 \\
$\mathrm{Cd}$ & $<0.01$ & $<0.01$ & $<0.01$ & 1.0 \\
$\mathrm{~Pb}$ & $0.032 \pm 0.01$ & $<0.01$ & $<0.01$ & 0.5 \\
$\mathrm{Ni}_{\mathrm{Co}}$ & $<0.01$ & $<0.01$ & $<0.01$ & 1.0 \\
$\mathrm{Co}$ & $0.100 \pm 0.00$ & $\mathrm{ND}$ & $0.300 \pm 0.00$ & 0.5 \\
$\mathrm{Cl}$ & $51.69 \pm 0.01$ & $55.52 \pm 0.01$ & $4.21 \pm 0.00$ & 600 \\
$\mathrm{NO}^{-}$ & $5.04 \pm 0.01$ & $7.28 \pm 0.01$ & $8.40 \pm 0.01$ & 20 \\
$\mathrm{PO}_{4}{ }^{-}$ & $0.98 \pm 0.01$ & $4.34 \pm 0.00$ & $1.79 \pm 0.01$ & 5.0 \\
$\mathrm{SO}_{4}{ }^{2-}$ & $3.59 \pm 0.00$ & $2.39 \pm 0.00$ & $3.54 \pm 0.00$ & 50 \\
\hline
\end{tabular}

PWW $=$ Process Water, $\mathrm{CW}=$ Clarified Water, FD $=$ Final Discharge, $\mathrm{ND}=$ Not Detected, $\mathrm{pH}$ has no unit, Temperature was measured in ${ }^{\circ} \mathrm{C}$

From the result presented in Table 1, it is seen that the major pollutant in the petrochemical plant is from Total Dissolved Solid (TDS) from process waste water PWW $(284.00 \pm 0.14 \mathrm{mg} / \mathrm{L})$, though significant amount of TDS is also present in CW and FD. 
The major sources of TDS in PWW are from toxic organics, heavy metals, spent caustic, distillation residues associated with units handling acetaldehyde, acetonitrile, benzyl chloride, carbon tetrachloride, cumene, and other raw materials use as feedstock in the plant. Current observations show that the PWW consist of product tank drains and spent caustic water as well as storm runoffs which contain large quantities of waste matters especially phenol $(12.75 \mathrm{mg} / \mathrm{L})$. The observed values for TDS of in all the three samples analyzed (PWW, CW and FD) were all below the $2000 \mathrm{mg} / \mathrm{L}$ recommended for refinery effluents ${ }^{12}$.

The PWW was also responsible for the increased concentration of Total Hydrocarbon THC $(0.79 \pm 0.00 \mathrm{mg} / \mathrm{L})$, though THC was not detected in CW and FD. The presence of THC in PWW is due to the fact that the major feedstock in a Petrochemical plant is Hydrocarbon. However, the concentration of THC was found to be lower than the maximum permissible limit of $10.00 \mathrm{mg} / \mathrm{L}$ for the effluent. Petroleum hydrocarbons have been observed to be toxic to aquatic life. It has further been reported that a water- accumulated fraction of hydrocarbon or dispersed crude oil water-accommodated fraction increased the activity of gill citrate synthase, $\mathrm{LDH}$, and hepatic ethoxyresorufin- $O$-deethylase (EROD) at a concentration of $14.50 \mathrm{mg} / \mathrm{L}^{6}$. Lipophilic hydrocarbons have been observed to accumulate in the membrane lipid bilayers of microorganisms and interfering with their structural and functional properties ${ }^{13}$. Grant and Briggs ${ }^{14}$ concluded that hydrocarbons are the most significant cause of toxicity in sediment samples. The presence of this concentration of THC in PWW, though in small amount require treatment by using ozone or passing the water under ultraviolet or other radiation ${ }^{15}$.

The concentration of TSS in FD was the highest $(78.89 \pm 0.00 \mathrm{mg} / \mathrm{L})$. This may be as a result of the inability of the final discharge pump to recycle the effluent within the pond or to return it to the equalization basin or surge pond ${ }^{16}$. Similarly, the high concentration of TSS in PWW may be as a result of the storage of all process waste water from the different plants and laboratory in the basin for further treatment. The concentration of TSS in FD was lowest because during treatment all forms of solids present in the water is sedimented and filtered and then sent to another basin for further treatment.

BOD is the measurement of the dissolved oxygen used by microorganism in the biological oxidation of organic matter. A high BOD value suggests more waste products or pollutants are present in the effluent. The concentration of BOD in FD $(6.12 \pm 0.00 \mathrm{mg} / \mathrm{L})$ was higher than the concentrations present in PWW and CW. This may be as a result of escape of organic matter from the biological treatment basin into the discharge pond, the most important of which could be the faecal waste deposition by the surrounding communities. Generally, the concentrations of BOD for PWW, CW and FD were all below the FEPA set standard.

The COD value of the petrochemical effluent analyzed were below the effluent limitation standard set by FEPA for refinery effluents in Nigeria largely as a result of the low COD values of the PWW which was channeled without treatment into the observation pond.

Other parameters that were significantly reduced in the samples of the petrochemical effluents analyzed were zinc, iron, magnesium, cadmium, lead, nickel and cobalt. The concentrations of all the metals analyzed fall below the FEPA set standard. Toxicity identification studies have indicated that accumulation of zinc for instance, may be the primary cause of toxicity in certain contaminated aquatic systems 5 . High concentrations of zinc have been observed to be specifically toxic to an aquatic insect Ranatra elongata 
$(1.658-2.853 \mathrm{mg} / \mathrm{L})$, and in the microtox test system $(1.35 \mathrm{mg} / \mathrm{L})^{17}$. Chen et al. ${ }^{18}$, gave the concentration of copper in an industrial soil as $26.10 \pm 19.6: \mathrm{gg}^{-1}$. Also a range of 0.01-59.89 $\mathrm{mg} / \mathrm{L}$ for copper has been reported in water logged sediment in the United Kingdom ${ }^{19}$. Significant concentration of nickel has been reported to be capable of accumulating in food chains and sometimes results in carcinogenic effect in humans ${ }^{20}$. Similarly, accumulation of cobalt could initiate or promote carcinogenic activities in animals ${ }^{21}$. The presence of lead in the soil sample may be as a result of wastes at the treatment site. Although the concentration of lead is very low in these samples, accumulations have been reported to induce abdominal pains, vomiting, drowsiness and paralysis of the liver and brain in humans ${ }^{22}$.

Phosphates and nitrates are components of agricultural fertilizers commonly used by farmers in the Niger delta area. These fertilizers may be leached into the soil and river bodies and thus may account for the significant concentrations observed in this study. It was observed that the concentration of phosphates was higher in CW than in PWW and FD while the concentration of nitrates was present in higher concentrations in FD than in PWW and $\mathrm{CW}$. These changes in concentration may be associated with the operations in the petrochemical plant that reduces the concentration of these compounds before finally discharging the effluent. Similarly, the concentrations of chlorides and sulphates were below FEPA recommended standard.

\section{Conclusions}

This study has shown that effluents from Eleme Petrochemical Company Limited generally contain low concentrations of pollutant in the water and sediment except the concentration of TDS that was higher than the FEPA recommended standard. The long-term impact of the petrochemical effluent on the surrounding environment is not known, though accumulation of these pollutants can be fatal to both aquatic and human life. Continued discharge of improperly treated effluent may further compound the environmental problems of the communities living around this company. An early resolution of the problem of treatment of the Eleme Petrochemical effluent is therefore imperative in order to save the receiving water body from further degradation.

\section{References}

1. Beg M U, Al-Muziaini S, Saeed T, Jacob P G, Beg K R, Al-Bahloul M, Al-Matrouk K, Al-Obaid T and Kurian A, Archives of Environmental Contamination and Toxicity, 2001,41, 289-297.

2. Beg M U, Saeed T, Al-Muziaini S, Beg K R. and Al-Bahloul M, Ecotoxicol Environ Saf., 2003, 54, 47-55.

3. Laroche G, Environmental Protection Agency. University of Houston, Texas, 1992, 199-206.

4. Suleimanov R A, Meditsina Trudai Promyshlennaia Ekologiia, 1995, 12, 31-36.

5. Bay S, Jones B H, Schiff K and Washburn L, Marine Environmental Research, 2003, 56, 205-223.

6. Kuehn R L, Berlin K D, Hawkins W E and Ostrander G K, J. Toxicology and Environmental Health, 1995, 46, 101-116.

7. Onwumere B G and Oladimeji A A, Ecotoxicology and Environmental Safety, 1990, 19, 123-134. 
8. Williams S, Official Method of Analysis of the Association of Analytical Chemists, 14th ed. A.O.A.C. Inc., Washington D.C, USA, 1984.

9. ASTM, Annual Book of ASTM Standards. Water and Environmental Technology, Philadelphia, U.S.A., 1989, 515-588.

10. Ademoroti C M A, Standard Methods for Water and Effluent Analysis, Foludex Press Ltd., Ibadan, 1996.

11. Stewart E A, Grimsham H M, Parkinson J A and Quarmby C, Chemical Analysis of Ecological Materials. Blackwell Scientific Publications, Oxford, 1974.

12. FEPA (Federal Environmental Protection Agency), National Guidelines and Standards for Waste Management in Oil and Gas Industry in Nigeria. FEPA (Nigeria) Official Gazette, Nigeria, 1991.

13. Sikkema J, de Bont J A and Poolman B, Microbiology Review, 1995, 59, 201-222.

14. Grant A and Briggs A D, Marine Environmental Research, 2002, 53, 21-48.

15. Udoessien E I, Pollution in Petroleum and Allied Industries MEF Nigeria Ltd Uyo, 1997.

16. Akpan D J, Water Pollution Control: A Case Study of NNPC/EPCL Effluent Treatment Plant. Unpublished PG. Thesis, University of Port Harcourt, Rivers State, 1998, 39.

17. Shukla G S and Omkar M R, Toxicology Letters, 1983, 15, 39-41.

18. Chen T B, Wong J W C, Zhon H T and Wong H M, Environmental Pollution, 1996, 96(1), 61-68.

19. Boult G H and Bruggerwert M G W, Soil Chemistry, Elsevier Scientific Publishing Company, Amsterdam, Oxford, 1976, 19.

20. Forstner U and Wittman C, Metal Pollution in the Aquatic Environment, Springer Verlag, Berlin, 1993, 4, 86.

21. Udosen E D, Aqua-Terrestrial Environmental Pollution Studies of Inorganic Substances from Two Industrial Firms in Akwa Ibom State. Unpublished Ph.D. Thesis, University of Lagos, Nigeria, 1991, 49.

22. Goldsmith, E and Hildyard, N, The Earth Report. The Essential Guide to Global Ecological Issues, Prince Sterm Sloan Inc., Los Angeles, 1988, 173. 


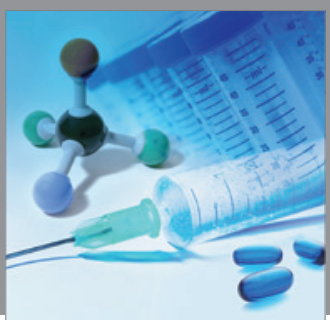

International Journal of

Medicinal Chemistry

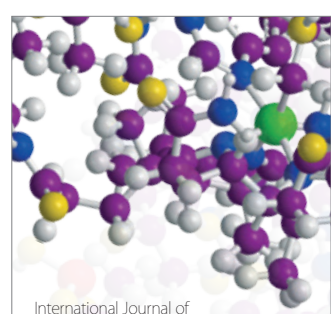

Carbohydrate Chemistry

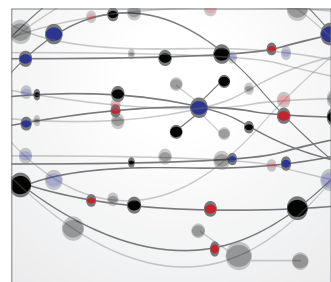

The Scientific World Journal
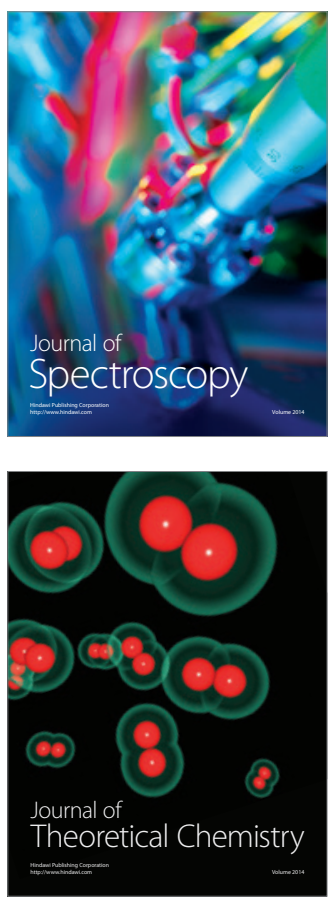
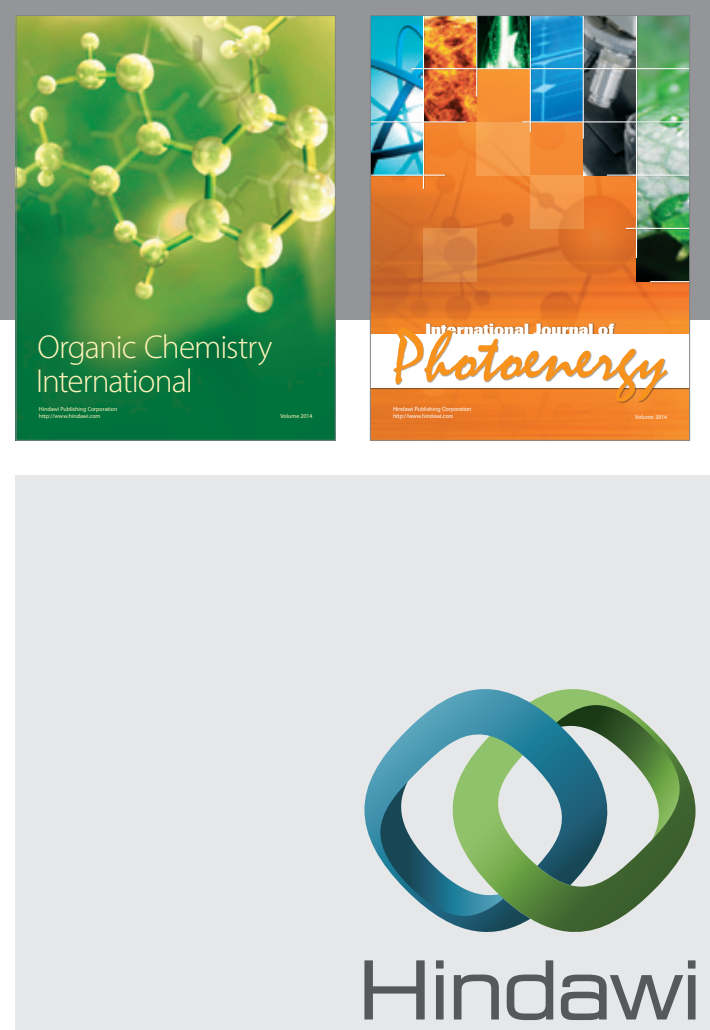

Submit your manuscripts at

http://www.hindawi.com
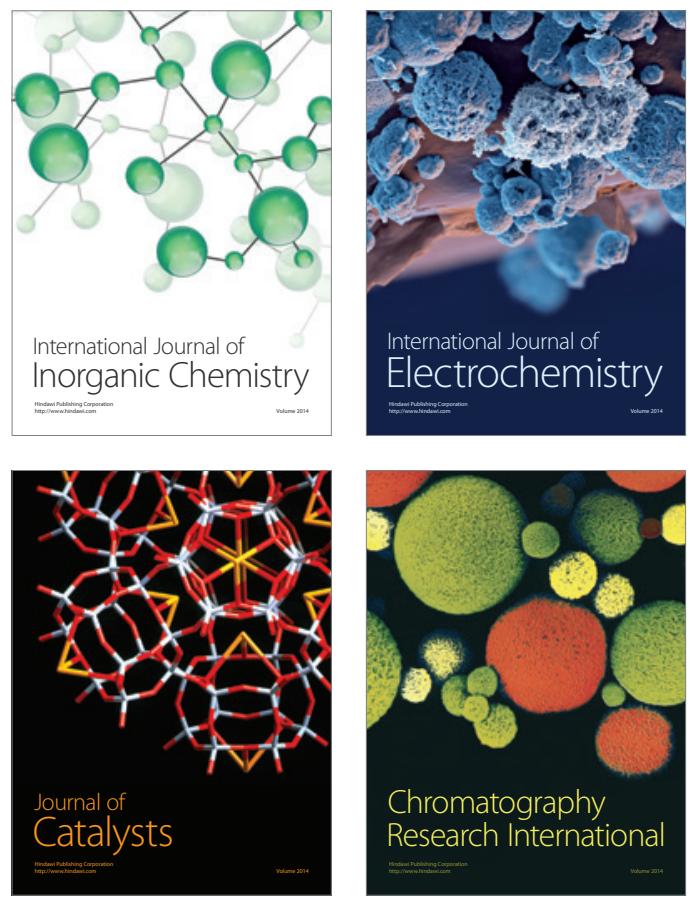
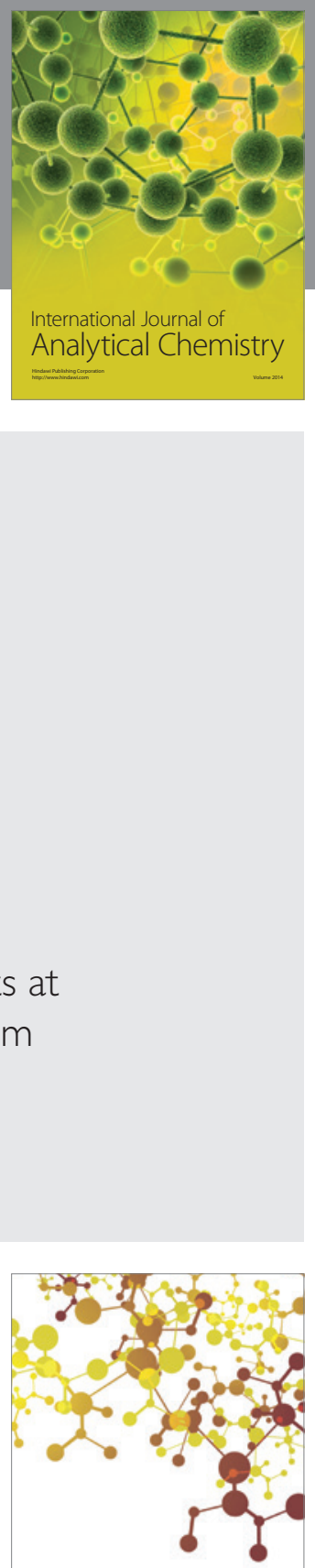

Journal of

Applied Chemistry
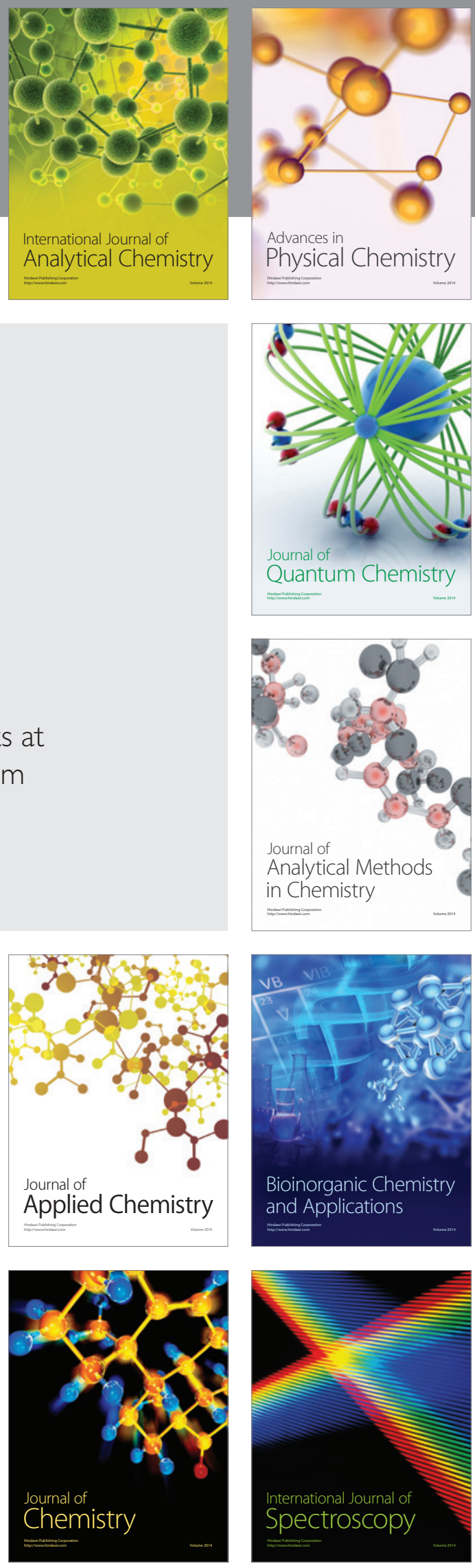